\title{
低分子化合物による溶媒の増粘とゲル化
}

\section{Thickening and Gelation of Solvents by Low Molecular Weight Compounds}

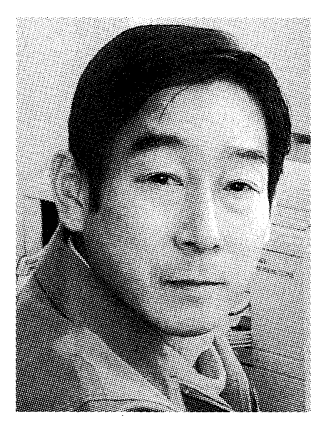

\author{
英 謙二 \\ 信州大学大学院工学系研究科 \\ T 386-8567 \\ 上田市常田 3-15-1
}

Kenji HANABUSA

Graduate School of Science and Technology,

Shinshu University

386-8567 Tokida 3-15-1, Ueda, Japan

論文要旨：溶媒に添加すると増粘現象を起こしたりゲル化したりする低分子化合物を紹介した。前者は増 粘剤とよばれ, 後者はゲル化剂と呼ばれる。増粘現象やゲル化の原動力はともに水素結合や静電相互作用, ファンデルワールスカ, $\pi-\pi$ 相互作用などの非共有結合である。

たとえば，トリ 3,7-ジメチルオクチル 1,3,5-ベンゼントリカルボキサミドはシクロヘキサンを増粘し， 30 $\mathrm{gL}^{-1}$ の濃度では $20^{\circ} \mathrm{C}$ で 20,000 cPになる。トリ 3,7-ジメチルオクチル cis-1,3,5-シクロヘキサントリカルボキ

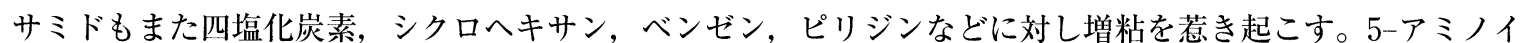
ソフタル酸ジメチルから合成した1-オクタデシルアミノ-3,5-ビス(2-エチルヘキシルアミノカルボニル)ベン ゼンはへキサン，シクロへキサン，芳香族溶媒，メタクリル酸メチル，スチレン，軽油などを増粘化する。 特に $15 \mathrm{gL}^{-1}$ のトルエン溶液の粘度は $20^{\circ} \mathrm{C}$ では $38,500 \mathrm{cP}$ である。また，その粘度は温度上昇とともに劇的に 低下する。

ゲル化剤としてアミノ酸誘導体，環状ジペプチド，アミホープ LL ${ }^{\circledR}$ 誘導体，trans-1,2-シクロヘキサンジ アミン誘導体を紹介した。ゲル化剤によるゲル化はゲル化剂分子が水素結合や静電相互作用，ファンデル ワールスカ， $\pi-\pi$ 相互作用などの非共有結合をと执して自己会合し高分子様の巨大会合体に成長し，絡まっ て 3 次元網目構造を作るために起こる。一方, 増粘現象は 3 次元網目構造ではなく高分子様の超分子集合体 を形成する。3 次元網目構造を形成できないとき増粘剂としての性質が現れると考えられる。

\begin{abstract}
Low molecular weight compounds, which can thicken and gel up solvents, were introduced. The former compounds are called "thickeners" and the latter ones are called "gelators". The driving forces for thickening and gelation phenomena are non-covalent bonds such as hydrogen bonding, electrostatic interaction, van der Waals interaction and $\pi-\pi$ interaction.

Tri (3,7-dimethyloctyl) -1, 3, 5-benzenetricarboxamide shows significant thickening effect for cyclohexane; the viscosity of the cyclohexane solution $\left(30 \mathrm{gL}^{-1}\right)$ exhibited over $20,000 \mathrm{cP}$ at $20^{\circ} \mathrm{C}$. Tri $(3,7-$ dimethyloctyl) cis-1,3,5-cyclohexanetricarboxamide also increased the viscosity against carbon tetrachloride, cyclohexane, benzene, and pyridine. 1-Octadecylamino-3,5-bis (2-ethylhexylaminocarbonyl) benzene, derived from dimethyl 5-aminoisophthalate, acts as a thickener for hexane, cyclohexane, aromatic solvents, methyl methacrylate, styrene, and light oil. For example, the compound shows significant thickening effect for toluene; the viscosity of the toluene solution $\left(15 \mathrm{gL}^{-1}\right)$ exhibited over $38,500 \mathrm{cP}$ at $20^{\circ} \mathrm{C}$. The viscosity of the toluene solution drastically decreases with increasing temperature.

Amino acid derivative, cyclo (dipeptide), amihope LL $^{\circledR}$ derivative, and trans-1,2-diaminocyclohexane derivative are described as gelators. When the gelation happens, the gelator molecules self-assemble into macromolecule-like aggregates via non-covalent intermolecular interactions such as hydrogen bonding, $\pi-\pi$ stacking, and van der Waals interactions. On the other hand, when thickening phe-
\end{abstract}

連絡者：英 謙二

E-mail : hanaken@giptc.shinshu-u.ac.jp 
nomenon occurs, the macromolecule-like supramolecular assembles are formed, but not a three-dimensional network. The lack of ability of formation of three-dimensional network will brings about the properties as thickeners.

Key words: Thickener, Gelator, Non-Covalent Bond Interaction, Hydrogen Bonding

\section{1 はじめに}

高分子化合物による溶媒の増粘やゲル化は古くから知 られている現象である。たとえば，沉用高分子のポリス チレンやポリメタクリル酸メチルをトルエンに溶かすと 増粘し粘稠液となる。また, 天然多糖の寒天（アガー） を熱水に溶かし冷やすとゲル化しヒドロゲルが形成され る。前者の汎用高分子による増粘はその巨大な分子長に 起因し, 後者は天然多糖のアガーが冷却時に高分子鎖間 の相互作用により絡まり三次元網目構造を作り物理ゲル 化するために起こる。このように増粘やゲル化といった コロイド的な挙動は高分子化合物に普通に観察される が，低分子化合物にもまれに同様の挙動が観察される場 合がある。これは低分子化合物が非共有結合的な分子間 相互作用により自己集合し，あたかも高分子のように振 る舞うからである。本稿では低分子化合物による溶媒の 増粘とゲル化について筆者の研究を中心に述べる。

\section{2 低分子化合物による溶媒の増粘現象}

低分子化合物の増粘剤の特徵は加熱時に溶媒に容易に 溶け, 少量の添加で数万 $\mathrm{cP}$ の高い粘性を示すことであ る。また，その粘稠液を加熱すると粘性は劇的に低下 し，ほとんど純粋な溶媒と同じ粘性になる。一方，汎用 高分子は溶媒に溶かすのに長時間を要し, その粘稠液は 加熱してもその粘性はほとんど低下しない。

増粘現象を惹き起こす低分子化合物としてはすでに Fig. 1 に示す 2-エチルヘキサン酸アルミニウム (1)が知 られており, インキの分野で使われている。1 は炭化水 素系溶剤に室温で溶解し粘稠溶液を形成する。1 1 Fig. 2 に示す静電相互作用によって高分子様の会合体を形成 するために増粘現象を惹起すると考えられている。

\section{$2 \cdot 1 \quad 1,3,5-$ ベンゼントリカルボキサミド誘導体}

化合物 2 は $1,3,5$-ベンゼントリカルボニルトリクロリ ドと 3,7-ジメチルオクチルアミンの反応で容易に合成で き, DMSO, ベンゼン, トルエン, 四塩化炭素, 脂肪族 炭化水素, 灯油, シリコンオイルなどに対し増粘を惹き 起こす ${ }^{1)}$ 。たとえば，2のシクロヘキサン溶液 $\left(30 \mathrm{gL}^{-1}\right)$ は $20^{\circ} \mathrm{C}$ で $20,000 \mathrm{cP}$ の粘性を示す。 2 は分子内に 3 個の アミド結合を有するため分子間水素結合によりカラム状 の高分子ともいうべき超分子を形成するためである。 Fig. 3 は 2 のデカン溶液 $\left(20^{\circ} \mathrm{C}\right)$ の動的粘弾性測定の結

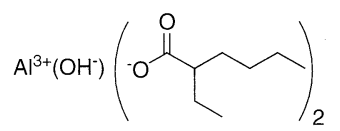

1<smiles>CC(C)CCCC(C)CCNC(=O)c1cc(C(=O)NCCC(C)CCCC(C)C)cc(C(=O)NCCC(C)CCCC(C)C)c1</smiles><smiles>CC(C)CCCC(C)CCNC(=O)C1CC(C(=O)NCCC(C)CCCC(C)C)CC(C(=O)NCCC(C)CCCC(C)C)C1</smiles><smiles>CCCCCCCCCCCCCCCCCC(=O)Nc1cc(C(=O)NCC(CC)CCCC)cc(C(=O)NCC(CC)CCCC)c1</smiles>

Fig. 1 Chemical Structure of 1-4.

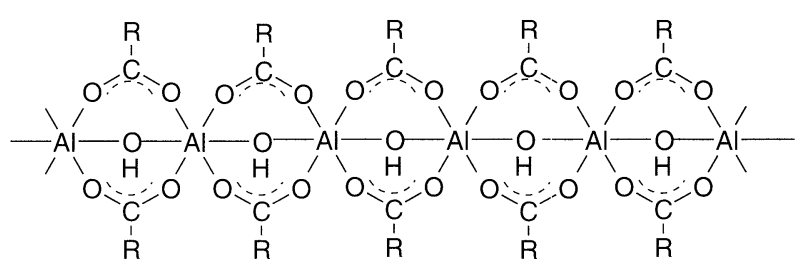

Fig. 2 Electrostatic Interaction of Aluminum bis(2-ethylhexanoate) 1.

果を示している。振動数 $\omega$ と貯蔵弾性率 $\mathrm{G}^{\prime}$, 損失弾性 率 $\mathrm{G}^{\prime \prime}$ の関係から 2 のデカン粘稠液は Maxwell モデルに 従うことがわかっだ2。 。た, 濃度とゼ口応力粘性率 $\eta_{0}$ の関係から，絡まりあった超分子集合体間のほどけ方は “reptation model”や “living polymer model”では説明 できず，超分子集合体を形成する 2 の解離と会合によっ て超分子集合体が幽霊のごとく通り抜ける“phantom crossing model”でうまく説明できる ${ }^{2)}$ 。Fig. 4 は phantom crossing model の概念図である。 


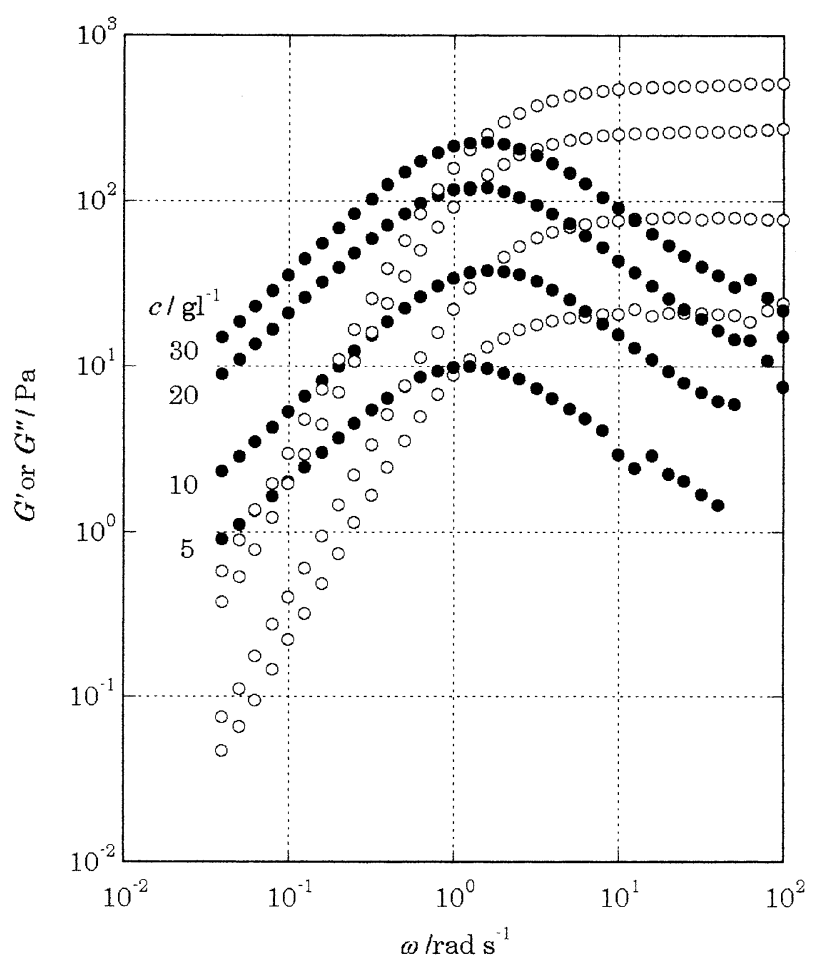

Fig. 3 Frequency, $\omega$, Dependency of Storage and Loss Moduli, $G^{\prime}$ and $G^{\prime \prime}$, for 2 in Decane with Various Concentrations, c, at $20^{\circ} \mathrm{C}$.

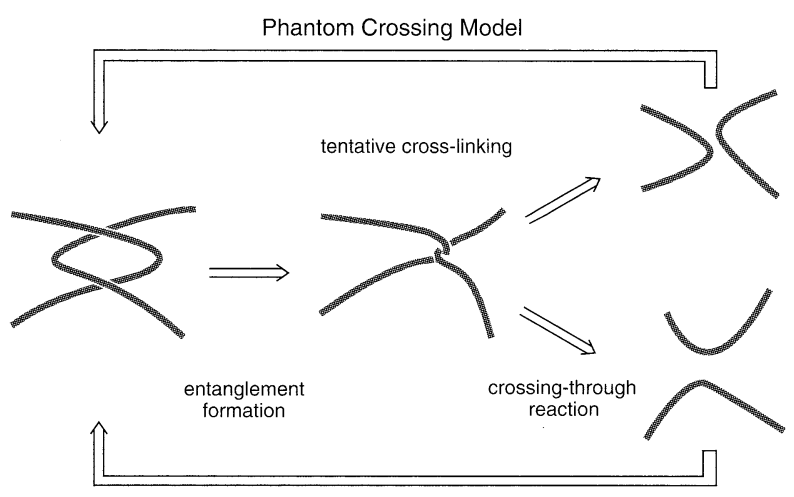

Fig. 4 Schematic Representation of a Phanton Crossing Model for an Entanglement Release Mechanism in Chainlike Substances.

\section{$2 \cdot 2$ cis-1, 3, 5-シクロヘキサントリカルボキサミド誘 導体}

cis-1, 3, 5-シクロヘキサントリカルボキサミド誘導体 3 も四塩化炭素, シクロヘキサン, ベンゼン, ピリジンな どに対し増粘を惹き起こす ${ }^{3,4)}$ 。たとえば，3の四塩化炭 素溶液 $\left(5 \mathrm{gL}^{-1}\right)$ は $25^{\circ} \mathrm{C} て ゙ 2,700 \mathrm{cP}$ の粘性を示す。 3 も 2 と同様に分子内に 3 個のアミド結合を有するため分子 間水素結合により高分子様の超分子を形成する（Fig. 5)。沉用高分子による増粘はその巨大な分子長に起因す るので電子顕微鏡観察してもその像（高分子鎖の 1 本ず つ）は捕まえることはできない。一方，低分子化合物に

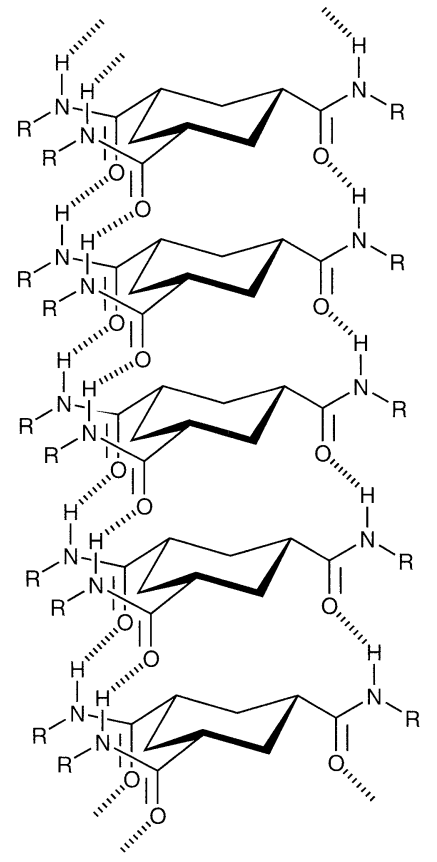

Fig. 5 Formation of Macromolecule-Like Aggregate by Intermolecular Hydrogen Bonding of 3.

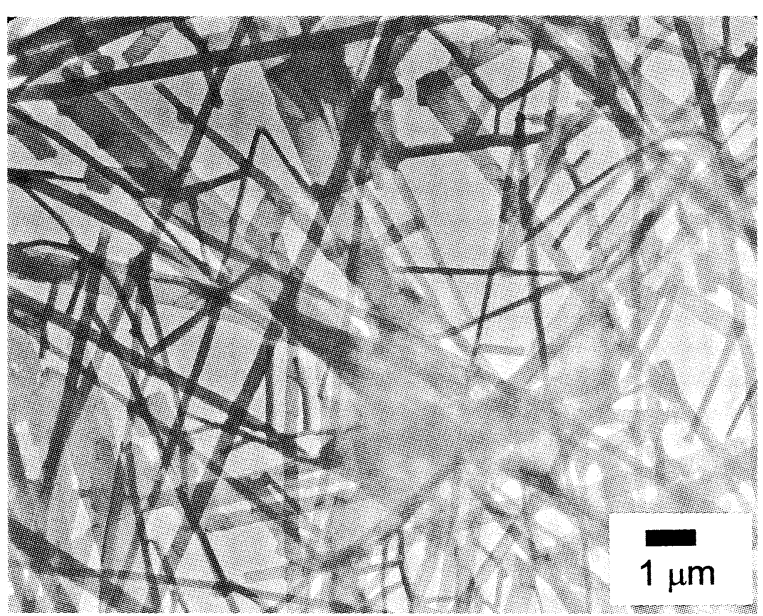

Fig. 6 TEM Image of Carbon Tetrachloride Highly Viscous Fluid Formed by 3, Negatively Stained by Osmic Acid.

よる増粘現象は高分子様の超分子集合体の形成に起因す るので，電子顕微鏡観察でその超分子集合体を見ること ができる。Fig. 6 は3 の四塩化炭素溶液中で形成される 会合体の TEM 像である。この像では小さなものでも幅 が $100 \mathrm{~nm}$ 以上あるので，電子顕微鏡で観察される超分 子集合体はFig. 5 に示したような分子レベルの集合体で はなく，分子レベルの集合体が無数に集合を繰り返した 後の巨大な会合体であると考えられる。

\section{$2 \cdot 3$ 5-アミノイソフタル酸誘導体}

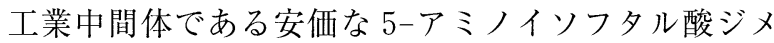
チルを原料に合成した化合物 4 は種々の脂肪族炭化水 素, ベンゼン, トルエン, クロロベンゼン，ニトロベン 
ゼン，スチレン，軽油などを増粘化する ${ }^{5)}$ 。5 位のアル カノイル基（化合物 4 ではn-オクタデカノイル基）は $\mathrm{n}$-ドデカノイル基や $\mathrm{n}$-ヘキサデカノイル基に変換して も増粘するが， 1 位と 3 位のアルキル基は 2-エチルヘキ シル基以外は結晶化するか良く溶けるかで増粘を起こさ ない。4のトルエン溶液 $\left(15 \mathrm{gL}^{-1}\right)$ の粘度の温度依存性 を Fig. 7 に示す。 $20^{\circ} \mathrm{C}$ では $38,500 \mathrm{cP}$ の粘稠液であるが $50^{\circ} \mathrm{C}$ では 9,200 cPにまで低下する。温度上昇に伴い分子 間水素結合が部分的に切れ，高分子様の超分子集合体が 切断されるので粘性が低下すると考えられる。

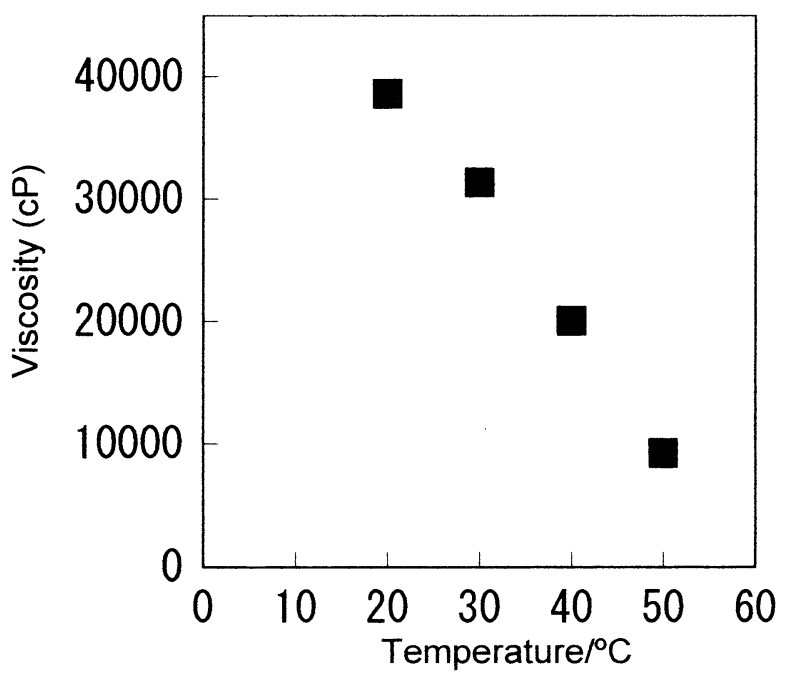

Fig. 7 Temperature Dependence of Viscosity of Toluene Solution of $4\left(15 \mathrm{mg} \mathrm{mL}^{-1}\right)$.

\section{3 低分子化合物による溶媒のゲル化}

増粘剂と比べ低分子化合物のゲル化剂は比較的多く報 告されている ${ }^{6-8)}$ 。また, Fig. 8 に示す化合物 5 〜 9 がゲ ル化剂として実用化されている。1,3;2,4-ジベンジリデ ン-D-ソルビトール (5) ${ }^{9)}$ はもっとも古いゲル化郕であり 広範囲の有機溶媒をゲル化できる。現在では，5はゲル 化剂として使用されるほかポリプロピレンの造核剂とし ても使われている。12-ヒドロキシステアリン酸(6) ${ }^{10)}$ は 廃てんぷら油のゲル化剤として利用されている。 N-ラウ

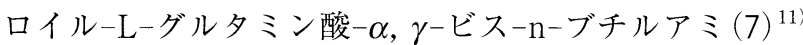
は化粧品原料として実用化されており，流出原油のゲル 化劑として原油の流出事故に備えて港湾に配備されてい る。ロジン由来のデヒドロアビエチン酸カルシウム塩 (8)は室温の廃てんぷら油に添加するだけでゲル化を起 こす特徵があり, 近日市販される予定である。尿素誘導 体 (9) は鉱物油をゲル化し，グリースを製造するために 利用されている。9 以外にも様々な尿素誘導体が製造さ れている。

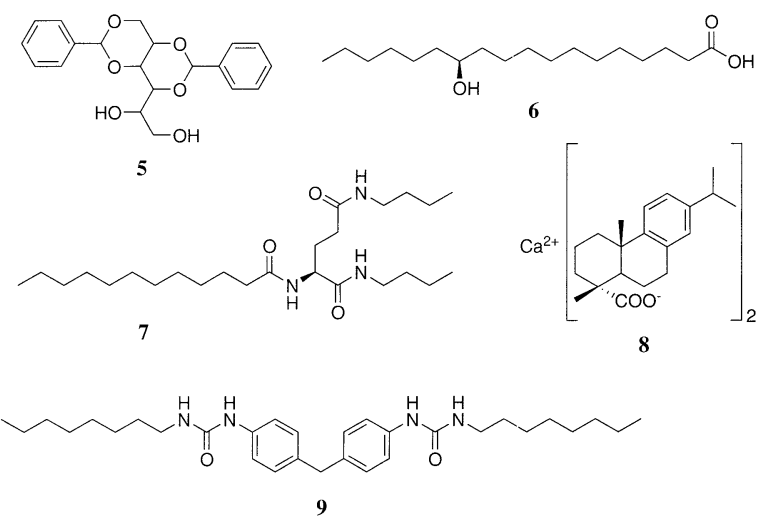

Fig. 8 Chemical Structure of Gelators Practically Used.

\section{$3 \cdot 1$ 低分子化合物の結晶化とゲル化}

低分子化合物によるゲル化は結晶化と均衡する現象で あり，比較して示すと Fig. 9のようになる。結晶を溶媒 中で加熱すると溶けて均一溶液となり，これを冷やすと 溶解度の差に応じて結晶化する (Fig. 9 の左半分)。しか し，まれに結晶化の代わりにゲル化する場合があり (Fig. 9 の右半分)，これが「低分子化合物による溶媒の ゲル化」である。ゲル化したゲルを加熱すると元の均一 溶液に戻る。左半分の結晶化は分子が凝集して 3 次元的 に秩序性のある配列をするために起こり，右半分のゲル 化は 2 次元的な配列で繊維状の会合体が形成され，さら に絡まって 3 次元網目構造を形成するために惹起され る。結晶化もゲル化も原動力は共に水素結合やファンデ ルワールスカなどの非共有結合的相互作用である。

低分子ゲル化剂の特徴を挙げると次のようになる。

(1)加熱時に容易に溶け，放冷時にすばやくゲル化す る

(2) 普通は $50 \mathrm{gL}^{-1}$ 以下の比較的少量の添加でゲル化す る

(3)形成されたゲルは熱可逆的なゾル・ゲル相転移を 示す

(4) ゲル化の原動力は水素結合，ファンデルワールス 力， $\pi-\pi$ 相互作用，静電相互作用などに代表され る非共有結合的な相互作用である

実際の低分子ゲル化剂によるゲル形成の手順を Fig. 10 に示す。ゲルの作製はきわめて簢単で，例えば（a）ゲ ル化剂を溶媒（この写真では $1.5 \mathrm{~g}$ の後述のゲル化剂 13 と $100 \mathrm{~mL}$ のトルエンに加え，（b）一旦加熱溶解させ， その後室温に戻す。すると, 放冷過程で直ちにゲル化し (c) のようなゲルが形成される。なお，ゲル化剤 13 と トルエンでは透明ゲルになるが，ゲル化剤の構造と溶媒 の種類に依存して透明，半透明，不透明ゲルが形成され る。 


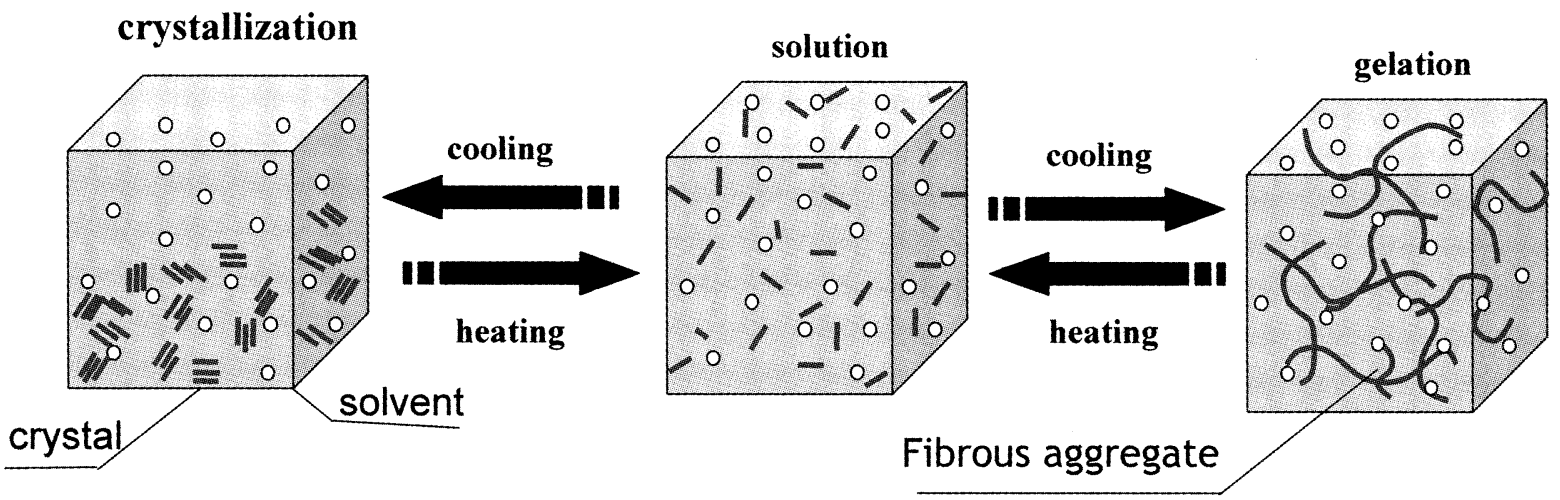

Fig. 9 Behavior of Low Molecular Weight Compounds.

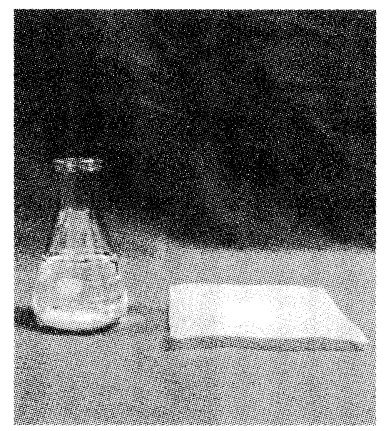

(a)

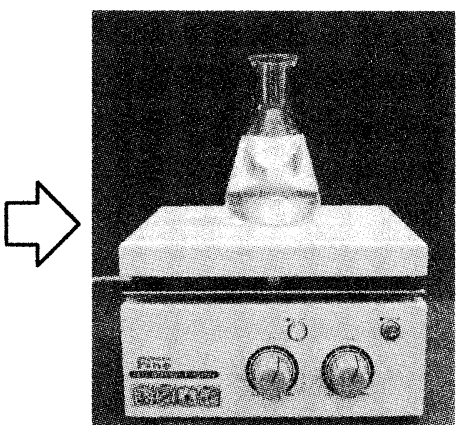

Solution

(b)

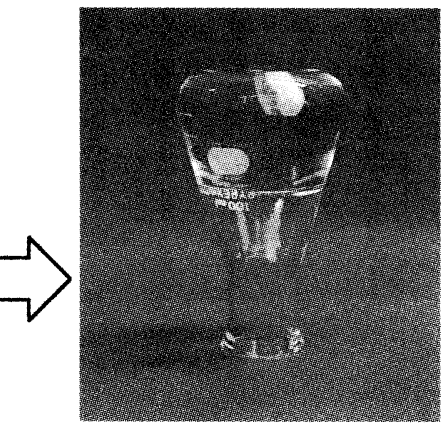

Gel

(c)

Fig. 10 Gelation Process of Solvent by Using Low Molecular Weight Gelator.

\section{$3 \cdot 2$ アミノ酸誘導体}

Fig. 11 に筆者らが開発した代表的なゲル化剂の構造を 示す。L-イソロイシン誘導体 $(10)^{12)}$ をはじめとする一 連のアミノ酸化合物には極めて強いゲル化能がある。特 に 10 の合成は $\mathrm{L}$-イソロイシンを出発原料にして 2 段階 の反応により容易に合成できる。10は Table 1 （ジメチ ルスルホキシドからシクロヘキサンまでは誘電率の高い 順に並べてある）に示すようにDMSO やDMF のよう な高極性溶媒・各種アルコール・ケトン・エステル・芳 香族化合物 ·四塩化炭素 ·炭化水素 ・ シリコンオイル 鉱物油・植物油など広範囲の液体をゲル化する。たとえ ば，10を $7 \mathrm{~g}$ 添加すれば $1 \mathrm{~L}$ のアセトンをゲル化でき， シリコンオイルは $5 \mathrm{~g}$ の添加で固化が可能である。しか し 10 のような構造のすべてのアミノ酸誘導体にゲル化 能があるわけではなく, 10 のアミノ酸部分のみを変化 させるなら L-Val にはゲル化能があるが，アミノ酸成分 が Gly, L-Ala, L-Leu, L-tert-Leu, L-Phe, L-Pro などは 結晶化するのみでゲル化はしない。また，ラセミ体の D, L-Val や D, L-Ile では結晶化する。

アミノ酸誘導体によるゲル化の主な原動力は分子間水

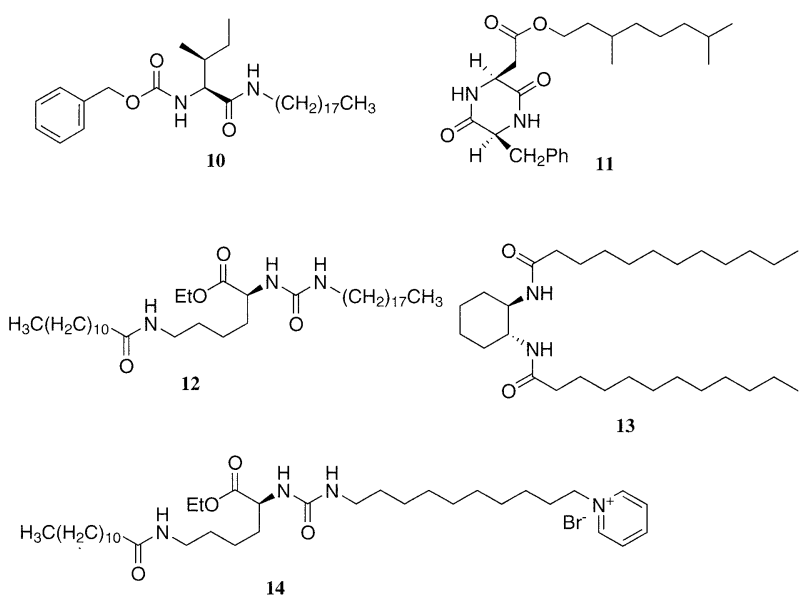

Fig. 11 Chemical Structure of 10-14.

素結合の形成である。Fig. 12 に 10 のシクロヘキサンゲ ルとクロロホルム溶液の FT-IR スペクトルを示す。10 のシクロヘキサンゲルの FT-IR スペクトルは NH 伸縮 振動が $3294 \mathrm{~cm}^{-1}$ に，ウレタンの $\mathrm{C}=\mathrm{O}$ 伸縮振動が 1689 $\mathrm{cm}^{-1}$ に，アミドの伸縮振動が $1645 \mathrm{~cm}^{-1}$ にあらわれウレ タン結合とアミド結合の $\mathrm{NH}$ と $\mathrm{C}=\mathrm{O}$ 間で水素結合が形 

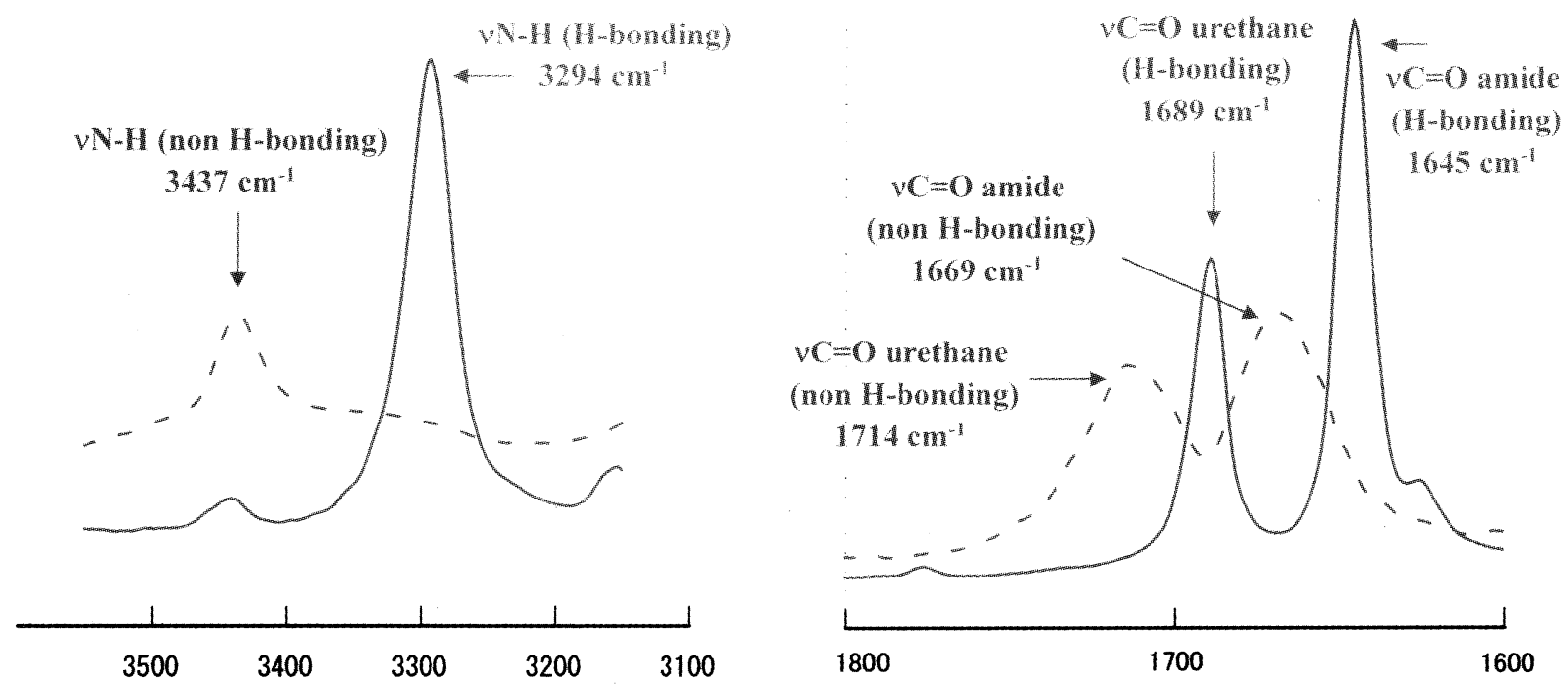

Fig. 12 FT-IR Spectra of Cyclohexane Gel (solid line) and Chloroform Solution (dash line) of Gelator 10.

Table 1 Minimum Gel Concentration of Gelator 10 Necessary for Gelation at $25^{\circ} \mathrm{C}$.

\begin{tabular}{lc}
\hline \multicolumn{1}{c}{ solvent } & $\mathrm{gL}^{-1}$ \\
\hline dimethyl sulfoxide & 10 \\
N,N-dimethylformamide & 20 \\
nitrobenzene & 22 \\
methanol & 19 \\
ethanol & 13 \\
1-propanol & 20 \\
acetone & 7 \\
cyclohexanone & 35 \\
2-propanol & 10 \\
1-butanol & 19 \\
Ethyl acetate & 18 \\
chlorobenzene & 30 \\
benzene & 10 \\
toluene & 36 \\
carbon tetrachloride & 20 \\
cyclohexane & 9 \\
silicone oil & 5 \\
light oil & 10 \\
kerosene & 11 \\
salad oil & 15 \\
soybean oil & 23 \\
\hline
\end{tabular}

成されており，非水素結合型の $\mathrm{NH}$ や $\mathrm{C}=\mathrm{O}$ はほとんど 存在しない。一方, ゲル化できないクロロホルム溶液で はクロロホルムにより 10 は溶媒和されるため, NH 伸 縮振動が $3437 \mathrm{~cm}^{-1}$ に, ウレタンの $\mathrm{C}=\mathrm{O}$ 伸縮振動が
$1714 \mathrm{~cm}^{-1}$ に，アミドの伸縮振動が $1669 \mathrm{~cm}^{-1}$ にあらわ れクロロホルム分子に溶媒和され非水素結合型である。

低分子化合物によるゲル化は，水素結合のような非共 有結合をとおして分子が自己会合し繊維状会合体を形成 し, 最終的に三次元網目構造を形成し溶媒分子を取り达 み進行する。つまり，ナノサイズの繊維状会合体がゲル 化の初期に必ず形成される。ゲル化剂の形成する繊維状 会合体は電子顕微鏡で容易に観察できる。Fig. 13 は Lバリンタイプのゲル化剂（10の L-イソロイシン残基が L-バリン残基に置き換わった化合物）の四塩化炭素希薄 ゲルをオスミック酸の蒸気でネガティブ染色して撮影し た TEM 写真である。幅が $10 〜 20 \mathrm{~nm}$ の繊維状会合体 が無数に集まり束になった巨大会合体が観察された。

筆者はアミノ酸系化合物によるゲル化の機構を次のよ うに考えている。アミド，ウレタンセグメントの分子間 水素結合により会合体を形成し，それが巨大会合体へと 成長する。続いてファンデルワールスカなどの相互作用 によりそれらが束になって網目状に絡まり相互に運動を 妨げあって流動性を失い，その中に溶媒を抱き込んでゲ ル化が起こる。

筆者は低分子ゲル化剂の開発のためには，以下の $3 つ$ の要素を分子設計に盛り込む必要があると考えている。

(a) 水素結合などの分子間相互作用による巨大繊維状 会合体の形成

(b)ファンデルワールスカなどによる繊維状会合体間 の結合・三次元化

(c)準安定状態であるゲルを安定化させ結晶化を妨げ る要因を有すること 


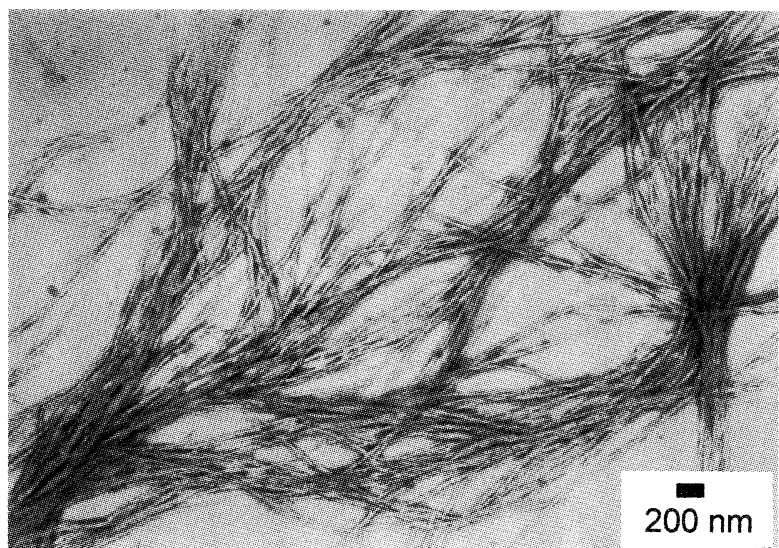

Fig. 13 TEM Image of Carbon Tetrachloride Gel Formed by 10, Negatively Stained by Osmic Acid.

\section{$3 \cdot 3$ 環状ジペプチド誘導体}

上記のゲル化剂としての必要条件 (a)〜 ( c) を満たす化 合物として環状ジペプチド誘導体に着目した。2,5-ジケ トピペラジン誘導体である環状ジペプチドは 6 員環構造 を有しており，2 個のアミド結合があるため Fig. 14 のよ うに分子間水素結合をと打して条件（a）の分子集合体 を形成すると考えられる。また分子間水素結合に欠陥点 が生じれば（b）の纎維状会合体の三次元化の原因とな る。そして $\mathrm{R}^{1}$ 基と $\mathrm{R}^{2}$ 基のランダム配列は結晶化を妨 げ，ゲル状態が安定化され（c）を満たすことになる。

実際，環状ジペプチド誘導体の 11 などにはゲル化能 がある ${ }^{13)}$ 。同一のアミノ酸成分からなる環状ジペプチド 誘導体はすべて結晶性がよく結晶化はするがゲル化はし

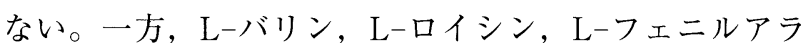
ニンのような中性アミノ酸と L-グルタミン酸- $\gamma$-エステ ル，L-アスパラギン酸- $\beta$-エステルのような酸性アミノ 酸という性質の異なる二つのアミノ酸を組み合わせた環 状ジペプチドはゲル化剤として作用する。中でも，人工

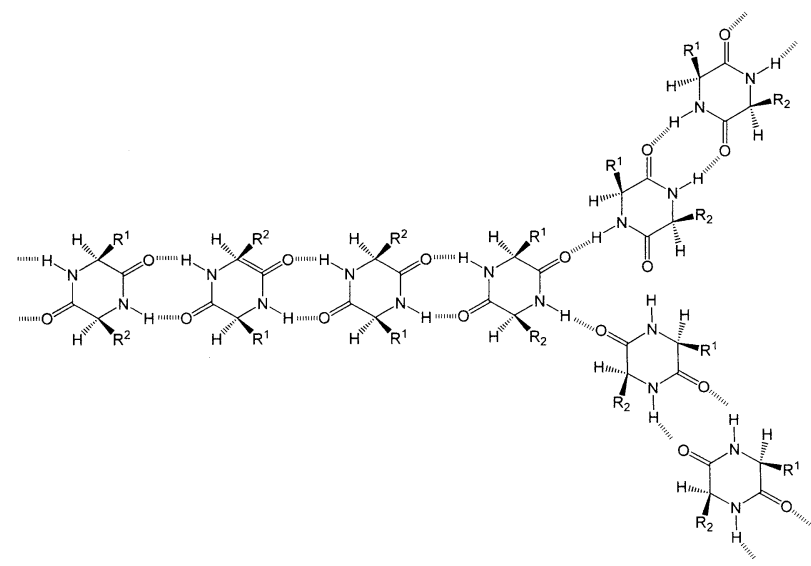

Fig. 14 Intermolecular Hydrogen Bonding of Cyclic (dipeptide).
Table 2 Minimum Gel Concentration of Gelator 11 Necessary for Gelation at $25^{\circ} \mathrm{C}$.

\begin{tabular}{lc}
\hline \multicolumn{1}{c}{ solvent } & $\mathrm{gL}^{-1}$ \\
\hline methanol & 44 \\
ethanol & 28 \\
acetone & 28 \\
ethyl acetate & 23 \\
carobn tetrachloride & viscous solution \\
cyclohexane & viscous solution \\
benzene & 10 \\
toluene & 3 \\
chlorobenzene & 11 \\
tricaprylin & 15 \\
triolein & 15 \\
soybean oil & 13 \\
decamethylcyclopentasiloxane & 5 \\
\hline
\end{tabular}

甘味料のアスパルテームをを原料として合成できる cyclo (L-Asp $\left.\left(\mathrm{OC}_{10} \mathrm{H}_{21}\right)-\mathrm{L}-\mathrm{Phe}\right)$ の 11 は Table 2 に示すように アルコール・エステル・ケトン・芳香族化合物・ダイズ 油・グリセリド，デカメチルシクロペンタシロキサンな どをゲル化できる特徽のあるゲル化剂である。Table 2 中のトリオレイン，トリカプリリン，デカメチルシクロ ペンタシロキサンは化粧品にしばしば使われる原料であ る。また，11はイミダゾリウム塩，ピリジニウム塩， アンモニウム塩などの多数のイオン性液体をゲル化でき るイオン性液体専用のゲル化剂でもある ${ }^{14)}$ 。

\section{$3 \cdot 4$ アミホープ LL ${ }^{\circledR}$ 誘導体}

さて，筆者らはゲル化剂の開発を研究テーマとしてい るが，常に念頭においていることがある。それはなるべ く廉価な原料から少ない反応段階で容易に合成でき，し かも強いゲル化能をもつゲル化剂を開発することであ る。すなわち誰もが合成でき，工場で製造してもコスト 的に採算があう単純な構造のゲル化剂の開発である。 $\mathrm{L}-$ リシン誘導体のゲル化剤 12 は, 工業製品のアミホープ $\mathrm{LL}^{\circledR}\left(\mathrm{N}^{\varepsilon}\right.$-ラウロイル-L-リシン）を原料にエステル化と イソシアン酸オクタデシルと付加反応という 2 段階反応 で合成できる ${ }^{15)}$ 。Table 3 に 12 がゲル化できる溶媒とそ の最小ゲル化濃度，および形成されたゲルの外見を示 す。12 はきわめて広範囲の溶媒をゲル化する。

\section{$3 \cdot 5$ trans-1, 2-シクロヘキサンジアミン誘導体}

trans-1,2-シクロヘキサンジアミンから 1 段階の反応 で合成されるジアミド $13^{16)}$ は，前述のペプチド誘導体 の $10 ， 12$ に匹敵する強いゲル化能をもつゲル化剂であ る。そのゲル化能は Table 4 に示したように広範囲の有 機溶剤をカバーしている。

1,2-シクロヘキサンジアミンには絶対配置が（1R, 2R） 
Table 3 Minimum Gel Concentration of Gelator 12 Necessary for Gelation at $25^{\circ} \mathrm{C}$ and Aspect of Formed Gel.

\begin{tabular}{|c|c|}
\hline solvent & $\mathrm{gL}^{-1}$ (aspect) \\
\hline hexane & 45 (translucent) \\
\hline cyclohexane & 30 (translucent) \\
\hline methanol & 30 (opaque) \\
\hline ethanol & 70 (opaque) \\
\hline ethyl acetate & 25 (translucent) \\
\hline acetone & 40 (opaque) \\
\hline 2-butanone & 45 (translucent) \\
\hline cyclohexanone & 50 (translucent) \\
\hline $\mathrm{THF}$ & 60 (translucent) \\
\hline 1,4-dioxane & 23 (translucent) \\
\hline benzene & 27 (transparent) \\
\hline toluene & 30 (transparent) \\
\hline chlorobenzene & 30 (transparent) \\
\hline nitrobenzene & 17 (transparent) \\
\hline pyridine & 35 (transparent) \\
\hline $\mathrm{N}, \mathrm{N}$-dimethylformamide & 40 (translucent) \\
\hline $\mathrm{N}, \mathrm{N}$-dimethylacetamide & 80 (translucent) \\
\hline dimethylsulfoxide & 25 (translucent) \\
\hline chloroform & $>100$ (translucent) \\
\hline carbon tetrachloride & 80 (translucent) \\
\hline acetonitrile & 25 (translucent) \\
\hline propylene carbonate & 25 (translucent) \\
\hline kerosene & 30 (translucent) \\
\hline light oil & 20 (translucent) \\
\hline silicone oil & 3 (transparent) \\
\hline salad oil & 6 (transparent) \\
\hline soybean oil & 6 (transparent) \\
\hline
\end{tabular}

と（1S, 2S）の 2 つのトランス体のほかにシス体の合計 3 個の異性体があるが，シス体から合成したジアミドと

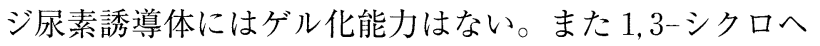
キサンジアミンや 1,4-シクロヘキサンジアミンから合成 した化合物にもゲル化能はない。CPK 分子模型を組む と，トランス体の 2 つの置換基はともにエクアトリアル 位にあり分子間水素結合による分子集合体の形成が可能 であるのに対し，シス体の場合は 2 つの置換基がアキ シャル位とエクアトリアル位にあるため分子間水素結合 は作れない。これがシス体にはゲル化能力がない理由で ある。なお，ラセミ体 ((1R, 2R) と (1S, 2S) の等量混合 物）から合成した 13 は特定の溶媒をゲル化できるが形 成されたゲルは不安定で数時間後には結晶へ転移する。

13 のゲルを TEM 観察（Fig. 15）したところ，ナノ繊 維状のらせん会合体が見られた。trans-(1R, 2R)から合
Table 4 Minimum Gel Concentration of Gelator 13 Necessary for Gelation at $25^{\circ} \mathrm{C}$.

\begin{tabular}{lc}
\hline \multicolumn{1}{c}{ solvent } & $\mathrm{gL}^{-1}$ \\
\hline dimethylsulfoxide & 12 \\
N, N-dimethylacetamide & 11 \\
acetonitrile & 5 \\
N, N-dimethylformamide & 10 \\
methanol & 20 \\
ethanol & 33 \\
2-butanone & 15 \\
cyclohexanone & 11 \\
2-propanol & 40 \\
pyridine & 25 \\
ethyl acetate & 8 \\
chlorobenzene & 22 \\
benzene & 20 \\
toluene & 12 \\
carbon tetrachloride & 23 \\
1,4-dioxane & 12 \\
cyclohexane & 7 \\
silicone oil & 6 \\
light oil & 7 \\
kerosene & 23 \\
salad oil & 12 \\
soybean oil & 2 \\
\hline
\end{tabular}

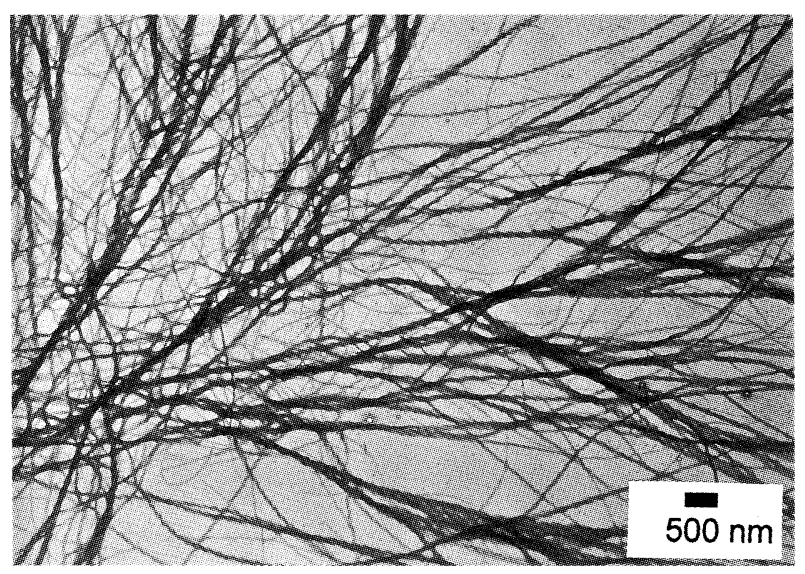

Fig. 15 TEM Image of Acetonitrile Gel Formed by 13, Negatively Stained by Osmic Acid.

成した 13 では左巻きのらせん会合体が形成され，trans(1S, 2S) から合成した 13 では右巻きのらせん会合体が観 察された。13 は非対称な分子間水素結合を作るため, アルキル基のついている片側が立体的にこみあうため， 会合体が曲がりその結果，らせん状会合体に成長すると 考えられる。分子レベルでの不斉が巨大会合体の不斉を 決定していることになる。 


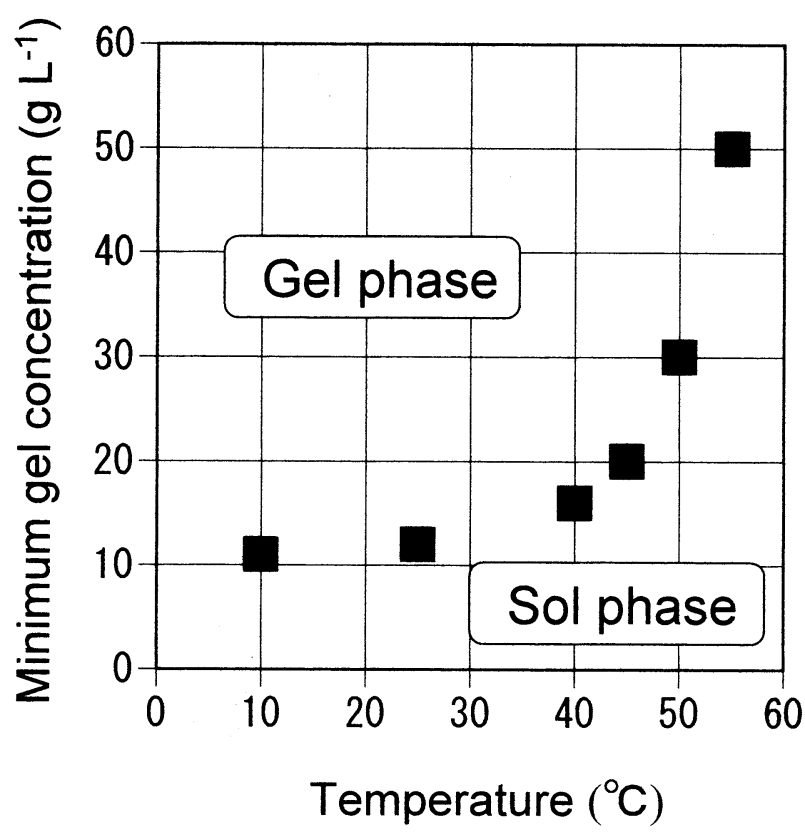

Fig. 16 Sol-Gel Phase Diagram; the Minimum Gel Concentration of 13 in toluene.

一般に低分子ゲル化剂のゲル化は温度依存性を示し， 高温の液体をゲル化するにはより多くのゲル化剂の添加 を必要とする。Fig. 16 はトルエン中の 13 の各温度にお ける最小ゲル化濃度をプロットして作成したゾル・ゲル 相図である。曲線の上方領域がゲル相，下方領域がゾル 相である。ゾル・ゲル相図より計算したゾルからゲルへ の転移時の熱力学的パラメーターは, $\Delta \mathrm{H}=-65 \mathrm{~kJ} \mathrm{~mol}^{-1}$, $\Delta \mathrm{S}=-160 \mathrm{JK}^{-1} \mathrm{~mol}^{-1}$ であり，ゲル化はエントロピー的 に不利な現象であるがそれをエンタルピー変化が補うエ ンタルピー支配的現象であることがわかる。低分子ゲル 化剤によってもたらされる物理ゲル化はすべてエンタル ピー支配的現象である。

\section{$3 \cdot 6$ ヒドロゲル化浏}

筆者は非共有結合としての水素結合を増粘剤やゲル化 剤の分子設計に積極的に利用してきた。水素結合を形成 するセグメントとしては水酸基やウレタン結合，アミド 結合，尿素結合などがあり，後の二つは特に強固な水素 結合を形成する。一般に水中では水素結合を形成しにく いと言われているが，これはまったくの迷信であると筆 者は思っている。実際，水酸基やウレタン結合，アミド 結合，尿素結合などを分子内に含む低分子化合物を熱水 から再結晶すると得られる結晶の IR スペクトルは必ず といってよいほど水素結合型のスペクトルとなる。つま り，水分子によって溶媒和され熱水中で溶けていた分子 が冷却過程で溶媒和水をリリースし，当該分子間で水素 結合が形成され結晶化するわけである。すなわち，当該 分子と水分子間の水素結合（溶媒和）よりも当該分子間
の水素結合が勝るとき結晶化することを意味している。 この事実はオイルゲル化剤の開発指針がそのままヒドロ ゲル化剤の分子設計に転用できることを示唆している。

上述のオイルゲル化剤の 5 〜 13 は加熱時も水に不溶 で水をゲル化することはできない。しかし，5～13に 親水性セグメントを導入すればヒドロゲル化剤となりう る。すなわち，親水性セグメントとゲル化駆動セグメン トを結合させれば，加熱時に親水性セグメントが働いて 水に可溶となり，放冷時にはゲル化駆動セグメント間の 水素結合が形成されて水をゲル化する。たとえば，L-リ シンを基盤としたゲル化剤の 12 は正電荷を導入するこ とによってヒドロゲル化剂 14 へ変換できる ${ }^{17)}$ 。14 は 0.3 $\mathrm{wt} \%$ でヒドロゲルを形成できる効果的なヒドロゲル化剂 である。また, $\mathrm{pH} 2$ ～ 12 の様々な水溶液, 生理食塩水, 各種無機塩を含む水溶液も比較的低濃度でゲル化が可能 である。なお，ヒドロゲル化剤については文献を参照さ れたい ${ }^{18)}$ 。

\section{4 おわりに}

溶媒に少量添加するのみで増粘を起こしたりゲル化し たりする低分子化合物を紹介した。このような増粘剤や ゲル化剤の開発はアカデミックな研究対象としてのみな らず実用面でも強い関心がもたれている。低分子化合物 による溶媒の増粘やゲル化の原動力は共に非共有結合に よる超分子集合体の形成である。実際，ゲル化剂を開発 する過程で増粘現象に出くわすことがしばしばある。ま た，構造が類似の化合物でもアルキル基の炭素数を変え たり，直鎖アルキル基から分岐アルキル基に変えたりす ると増粘ではなくゲル化したり，その逆であったりす る。さらに，溶媒にも依存し同じ化合物であってもゲル 化する溶媒と増粘する溶媒があったりする。しかし，い ずれにしても原動力である非共有結合による超分子の形 成は熱力学的により安定な結晶化につながるのが普通で あり，準安定状態の粘稠液やゲルを形成することは極め てまれである。筆者は長年，ゲル化剤や増粘剤の開発を 研究テーマとしてきたが未だに明確な分子設計の指針は ない。増粘とゲル化を分ける要因も不明である。読者の 中に化合物合成の途次で再結晶させようとして増粘現象 やゲル化に遭遇された経験のある人は, 是非思い起こし て論文にして欲しいものである。その構造が単純であれ ばあるほど，学問的にも興味深くまた実用化も期待され る。

\section{文献}

1) K. Hanabusa, C. Koto, M. Kimura, H. Shirai \& A. Kakehi, Chem. Lett., 1997, 429-30 (1997). 
2) T. Shikata, D. Ogata, \& K. Hanabusa, J. Phys. Chem. B, 108, 508-14 (2004).

3) K. Hanabusa, A. Kawakami, M. Kimura \& H. Shirai, Chem. Lett., 1997, 191-2 (1997).

4) T. Shikata, D. Ogata, \& K. Hanabusa, J. Soc. Rheol. Jpn., 31, 229-36 (2003).

5) D. Inoue, Y. Sakakibara, M. Suzuki, H. Shirai, A. Kurose \& K. Hanabusa, Chem. Lett., 33, 348 (2005).

6) P. Terech \& R. G. Weiss, Chem. Rev., 97, 3133 (1997).

7) J. H. Van Esch \& B. L. Feringa, Angew. Chem. Int. Ed., 39, 2263 (2000).

8) L. A. Estroff \& A. D. Hamilton, Chem. Rev., 104, 1201 (2004).

9) 山本偆一, 工業化学雑誌, 46, 779 (1943).

10) T. Tachibana, T. Mori \& K. Hori, Bull. Chem. Soc. Jpn., 53, $1714(1980)$
11）本間正男, 現代化学, 1987, 54 (1987).

12) K. Hanabusa, K. Hiratsuka, M. Kimura \& H. Shirai, Chem. Mater., 11, 649 (1999).

13) K. Hanabusa, M. Matsumoto, M. Kimura, A. Kakehi \& H. Shirai, J. Colloid Interface Sci., 224, 231 (2000).

14）英謙二，イオン性液体用ゲル化剂の開発とそのイオン 性液体ゲルの特徵, 化学工業, 55, 790 (2004).

15) K. Hanabusa, H. Nakayama, M. Kimura \& H. Shirai, Chem. Lett., 2000, 1070-430 (2000).

16) K. Hanabusa, M. Yamada, M. Kimura \& H. Shirai, Angew. Chem. Int. Ed. Engl., 35, 1949 (1996).

17) M. Suzuki, M. Yumoto, M. Kimura, H. Shirai, \& K. Hanabusa, Tetrahedron Lett., 45, 2947 (2004).

18）英謙二, 鈴木正浩, 高分子ゲルの最新動向, 梶原莞爾, 柴山充弘監修，シーエムシー出版，p27-44 (2004). 